\title{
円柱壁面近傍のシンセティツクジェットに関する実験的研究
}

\section{Experimental study of synthetic jet on a circular cylinder}

$\begin{array}{rllllll}\text { ○学 中川 盟士（工学院大院） } & \text { 正 } & \text { 西部 } & \text { 光一 (工学院大院) } & \text { 正 岡安 晋平 (工学院大院) } \\ \text { 正 佐藤光太郎 (工学院大) } & \text { 正 } & \text { 横田 } & \text { 和彦 (名工大院) } & & \end{array}$

Chikashi NAKAGAWA, Graduate School of Engineering, Kogakuin University, Nishi-Shinjuku 1-24-2, Shinjuku-ku, Tokyo

Koichi NISHIBE, Graduate School of Engineering , Kogakuin University

Shimpei OKAYASU, Graduate School of Engineering, Kogakuin University

Kotaro SATO, Kogakuin University

Kazuhiko YOKOTA, Nagoya Institute of Technology, Gokiso-cho, Showa-ku, Nagoya

Key Words : Synthetic Jet, Continuous Jet, Circular Cylinder, Speaker-Driven, Pressure Distribution, Velocity Distribution

\section{1. 緒言}

近年，シンセティックジェットに関する研究が盛んに行わ れている(1)-(4). シンセティックジェットは二次元スロットや オリフィスから往復振動流を発生させ，噴出・吸引を繰り返 すことで，下流に生じる連続噴流と類似の流れのことであ る. 吸引時には場全体から吸い込むのに対して噴出時には指 向性を有する噴流を形成するため速度せん断が生じ, 二次元 流れでは渦対，軸対象流れでは渦輪を形成する。スロット・ オリフィス出口での時間平均流量はゼロになるが，下流側で は渦対・渦輪の形成によりエントレインメントが生じて実質 流量が生まれる.シンセティックジェットでは連続噴流のよ うにコンプレッサやブロアなど大型機器を必要としないた め，翼面付近にアクチュエータを取り付けて翼の失速制御な どが試みられている(1),(2). 一方，シンセティックジェットの 流動特性の解明も始まっており, 噴流構造や非定常特性など (3),(4)が明らかにされている。しかし，これまでの研究報告で は，自由噴流を研究対象としたものがほとんどで，噴流のコ アンダ効果などシンセティックジェットと境界面との干渉 に着目した報告は見当たらない。本研究は円柱壁面近傍にお けるシンセティックジェットの流動特性を実験的に明らか にすることを目的として, 主に円柱表面圧力計測から連続噴 流との基本的流動特性の同異について議論する。

\section{2. 実験装置及び方法}

図 1 に本実験で用いた実験装置および試験部概略を示 す。(a)は実験装置の概略図, (b)は試験部の概略図である。図 1(a)のように円柱両端はアクリル板により保持されてい る. 供試円柱は直径 $D=100 \mathrm{~mm}(R=D / 2)$, スパン $l=100 \mathrm{~mm}$ で ありスパン方向に一定幅のスロットを備えている．スロット 幅bはスペーサーにより可変だが，本報告では $b=5 \mathrm{~mm}$ 一定と した（図 1(b)参照).シンセティックジェットはシグナルジ エネレータ(MCP LG1100D)とアンプ(Classic Pro V3000)に よりスピーカー(DIECOOK DD-15L)を駆動することで, 連続 噴流はブロア(富士電機モータ VFZ501A)を用いてプレナム に空気供給することで生成された。 スロット出口流速はそれ

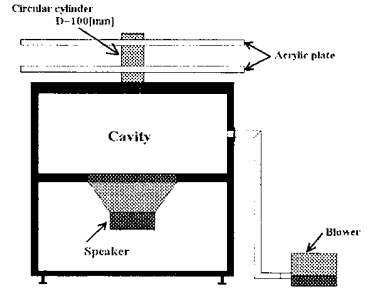

(a) Speaker-driven synthetic jet actuator

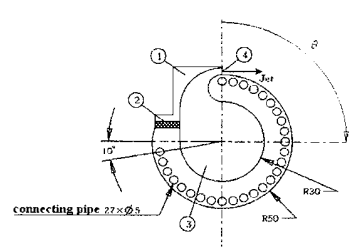

(b) Cross-section of a circular cylinder

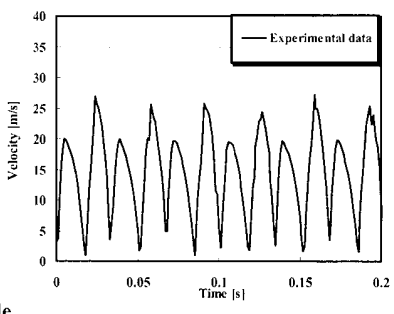

Fig.2 Definition of velocity in a synthetic jet

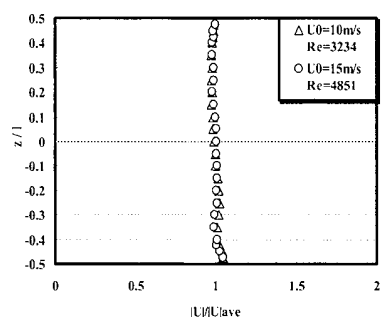

Fig.3 Two dimensional flow of a synthetic jet
でれシグナルジェネレータとインバータによって調整し，流 速計測には熱線流速計(KANOMAX IHW100)を使用した。(b) に示すように本実験ではスロットからの角度を $\theta$ と定義 し, 円柱表面の圧力計測については円柱本体表面上に静圧孔 を $\theta=0^{\circ}$ から $10^{\circ}$ おきにスパイラル状に設け，微差压計 $\left(\right.$ OKANO DMP301N)により計測した. 本研究ではHolmanら ${ }^{(4)}$ を参考にシンセティックジェットで得られた実験值をレイ /ルズ数 $R e=U_{0} b / v$ と無次元周波数の逆数である $K=1 / S t=R e / S^{2}$ で整理した。 ここで，Uoはシンセディックジェ ット出口速度，ストークス数は $S=\left[2 \pi f b^{2} / \nu\right]^{1 / 2}$ である。 $f$ は周 波数， $\nu$ は動粘性係数を表す。なお，本実験においてSはス ピーカー振動数，Reはスピーカー振幅で調整した。図 2 にス ロット出口におけるシンセティックジェットの速度絶対值 の時間変化を示す。測定位置は $\theta=0^{\circ}$ ，スパン方向中央部 $(Z / l=0)$, 半径方向位置はスロット幅中央の $r / R=1.05(\mathrm{r}$ は任 意の半径とする）である. 本図で大きな山部が噴出時，小さ い山部は本来, 負の值として評価される吸引時の速度絶対值 である．本研究では簡単のため噴出時のみを考慮して，その 波形は大力信号通りに正弦波 $|A \sin 2 \pi f t|$ が形成されるものと仮 定して振幅 $A$ を見積もり，代表速度 $U_{0}=f L_{0}=A / \pi$ を算出した (4)．なお，L $L_{0}$ はストローク長さである。図 3 に本実験装置の 二次元性を確認するためスロット出ロでのシンセティック ジェット速度分布を示す. 横軸は平均速度の絶対值を時間平 均した値 $|U|$ を空間平均した值 $|U|_{\text {ave }}$ で無次元化した值，縦軸 はスパン方向位置Z/である，各位置での速度の平均速度から のずれは最大で $2.5 \%$ 程度であり，出口ではほぼ二次元的な 流れが実現されていることが確認される。

\section{3 . 結果及び考察}

図 4 はいくつかの出口流速（Re数）に対する円柱表面圧力 分布である.(a)に連続噴流の圧力分布，(b)にシンセティック ジェットの場合の圧力分布を示す. 本図の条件の場合, 連続 噴流では明確な極值が認められないが，シンセティックジェ ットでは $U_{0}=5 \mathrm{~m} / \mathrm{s}$ 及び $U_{0}=15 \mathrm{~m} / \mathrm{s}$ で $\theta=50^{\circ}$ 付近, $U_{0}=10 \mathrm{~m} / \mathrm{s}$ では $\theta=60^{\circ}$ 付近に極值が存在する。極值の位置は出口流速だけて 


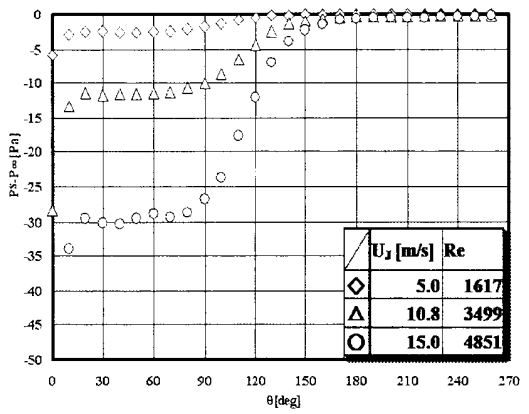

(a) continuous jet

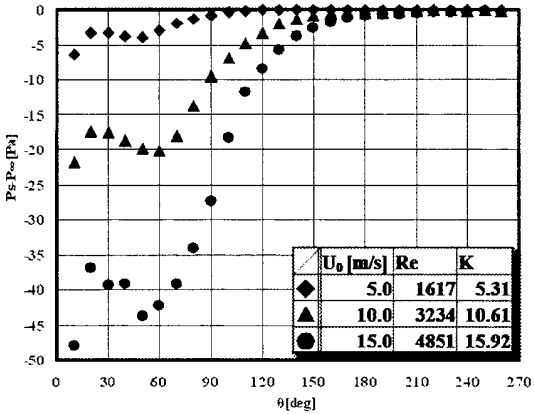

(b) synthetic jet ( $f=30 \mathrm{~Hz}$ )

Fig.4 Pressure distributions around the circular cylinder

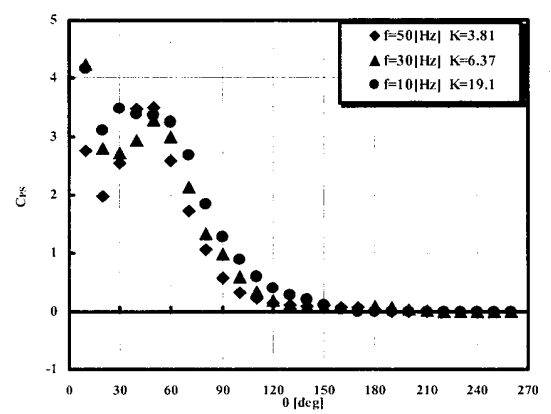

Fig.6 Pressure distributions of a synthetic jet

$\left(U_{0}=6 m / s \quad R e=1940\right.$, dependence on Stokes number)

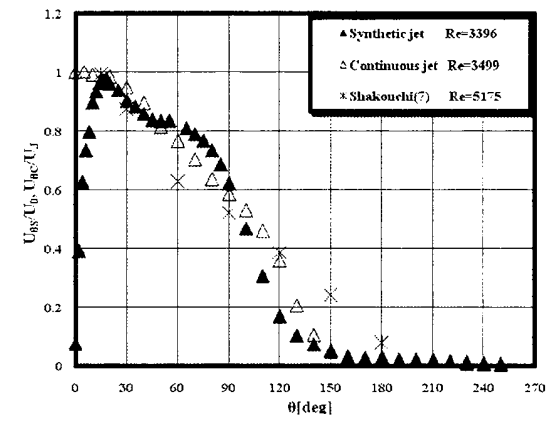

Fig.7 Velocity distributions around the circular cylinder $\left.\left(U_{0}=10.5[\mathrm{~m} / \mathrm{s}] \quad K=11.14 \quad f=30 \mid \mathrm{Hz}\right], \quad U_{J}=10.8 \mathrm{~m} / \mathrm{s}\right)$

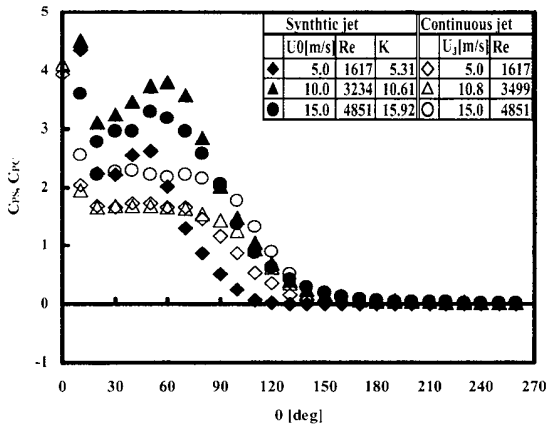

Fig.5 Pressure distributions of nondimensional flow $(f=30 \mathrm{~Hz})$

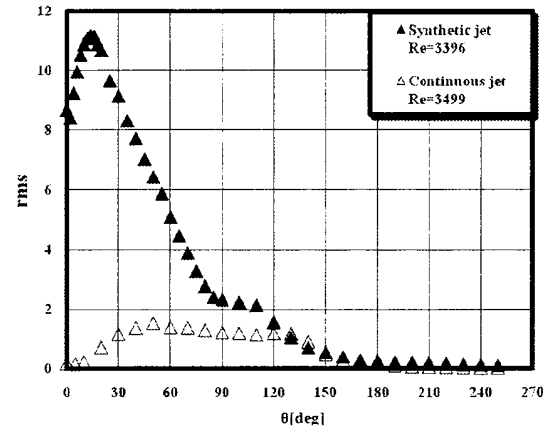

Fig.8 rms of velocity fluctuation

$\left.\left.\left(U_{0}=10.5 \mid \mathrm{m} / \mathrm{s}\right] \quad K=11.14 \quad \mathrm{f}=30 \mid \mathrm{Hz}\right], \quad U_{J}=10.8\right)$
決定されるのではなく，Kや幾何形状に依存して渦が巻き上 がり位置によって決まるものと考えられる．ところで八木田 $ら^{(5)}$ は変局点と分布曲線に接する直線と剥離後の分布曲線に 接する直線 $\left(C_{P}=0\right)$ との交点から剥離位置を概算しており，こ こでもこれに倣いおよその剥離点を求めてみる。連続噴流の 場合には出口流速が $U_{J}=5 \mathrm{~m} / \mathrm{s}(\diamond), 10 \mathrm{~m} / \mathrm{s}(\triangle), 15 \mathrm{~m} / \mathrm{s}(\bigcirc)$ と増 加すると, 剥離位置はそれぞれ, $\theta \fallingdotseq 130^{\circ} ， 140^{\circ}, 145^{\circ}$ に後 退している. 同样にシンセティックジェットでも $\mathrm{U}_{0}=5 \mathrm{~m} / \mathrm{s}(\bullet)$ では $\theta \fallingdotseq 90^{\circ}, U_{0}=10 \mathrm{~m} / \mathrm{s}(\boldsymbol{\Delta})$ では $\theta \fallingdotseq 120^{\circ}, U_{0}=15 \mathrm{~m} / \mathrm{s}(\boldsymbol{O})$ では $\theta \fallingdotseq 130^{\circ}$ と流速の増加とともに剥離位置が後退している。す なわち, 円柱曲面上でもシンセティックジェットによる平均 流は壁面に付着して流れることがわかる，なお，本条件では Re数とともにKも変化していることから本図の結果だけをも つて単純にRe数の影響について議論することはできない. 図 5 に連続噴流とシンセティックジェットの圧力係数 $C_{P}$ と $\theta$ の 関係を示す。ただし、Neuendorfら ${ }^{(6)} に$ 倣い連続噴流の圧力係 数を $C_{P C}=D\left(P_{\infty}-P_{S}\right) /\left(\rho U_{J}^{2} b\right)$, シンセティックジェットの圧力係 数 $C_{P S}=D\left(P_{\infty}-P_{S}\right) /\left(\rho U_{0}^{2} b\right)$ と定義し, 整理をした. Neuendorf ${ }^{(6)}$ は高Re数の場合に着目していることから圧力分布はRe数に 依らずほぼ 1 本の曲線上に分布しているが，Re数が比較的低 い本実験条件では值はRe数に依存している，図 6 に $U_{0}=6 \mathrm{~m} / \mathrm{s}$, $R e=1940$ でのK（または $S$ ) をパラメータとしたシンセティッ クジェットの $C_{P S}$ と $\theta$ の関係を示す. 図 4 同様に剥離点を求め ると・では $\theta \fallingdotseq 95^{\circ}$ ムでは $\theta \doteqdot 100^{\circ}$ ○では $\theta \fallingdotseq 110^{\circ}$ で剥離し ているものと推察される。本実験範囲では $K$ 古さきなるに 従って剥利点は下流側に後退するものと思われる. 図 7 に $U_{J}=10.8 \mathrm{~m} / \mathrm{s}, U_{0}=10.5 \mathrm{~m} / \mathrm{s}$ の条件下寸なわち, それぞれ $R e=3499$, $R e=3396$ における $r / R=1.05$ での連続噴流とシンセティックジ エットの流速変化を示す, 横軸は角度 $\theta$, 縦軸は時間平均周 方向速度 $(r / R=1.05$ での $r$ 方向速度は周方向速度に比心゙小さい として無視する）でシンセティックジェットでは $U_{O S}$, 連続 噴流では $U_{0 C}$ である。なお，比較のため同図にRe=5175 の社 河内ら ${ }^{(7)}$ の実験結果を示す. 連続噴流の場合は当然ながら出 口流速が最大になっているが，シンセティックジェットの場 合には振動流であるため時間平均すると出口流速は小さい
が急激に増加して $\theta=15^{\circ}$ 付近で最大值を示す. 図 8 に図 7 と 同条件下で計測された $r m s$ 值を示す。出口近傍でのシンセテ イックジェットの rms 值は連続噴流の值を大幅に上回ってい る. 図 6 同様, シンセティックジェットのrms 值も $\theta=15^{\circ}$ 付 近で最大となる。しかし， $\theta>130^{\circ}$ では両者に明確な差異は 無く, シンセティックジェットでも平均流形成後であるこの 領域では非定常特性に関して連続噴流と同様に取り扱える ものと考えられる。

\section{4. 結論}

本研究では円柱壁面シンセティックジェットの流動特性 の解明を目的として実験的に研究を行った．主な結論を以下 に示す。

1. 円柱壁面上でもシンセティックジェットは生成され, ス ロット下流に形成される平均流は壁面に付着して流れ ることが確認された。

2. 連続噴流の圧力分布には極值は存在しないのに対し て，本実験条件範囲のシンセティックジェットでは $\theta=50 \sim 60^{\circ}$ 付近に圧力極小值が存在する.

3. 同一半径上 $r / R=1.05$ では $r$ 方向速度, $r m s$ 値ともに $\theta=15^{\circ}$ 付近で最大となることがわかった。

本研究を遂行するにあたり, 三重大学 社河内敏彦教授, 九 州大学 高曾徹准教授から貴重なご助言を頂きました。ここ に記して謝意を表します。

\section{参考文献}

(1) Duvigneau, R. et al., ASME J. Fluids Engineer., 2007, 129, 825-833

(2) You, D. and Moin, P., Annual Research Briefs 2007, Center for Turbulence Research, 311-321

(3) Smith, B, L. and Glezer, A., 1998, 10(9), 2281-2297

(4) Holman, R. and Utturkar, Y., AIAA Journal, 2005, 43, pp.2110-2116

(5)八木田幹・ほか 2 名, 機論, 70-691,B(2004), 594-601

(6) Neuendorf, R. and Wygnanski, I., J. Fluid Mech., 1999, 381, pp.1-25

(7) Shakouchi, T. et al., JSME International Journal,1989, Series II, 32, 332-339 